\title{
Probabilistic seismic performance assessment of brick masonry infill reinforced concrete building
}

\author{
V. S. Patil ${ }^{1}$ S. N. Tande ${ }^{2}$ \\ Received: 24 July 2017 / Accepted: 18 August 2018 / Published online: 23 August 2018 \\ (c) The Author(s) 2018
}

\begin{abstract}
The present study aims at investigation of seismic performance of brick masonry infill (BMI) reinforced concrete building through probabilistic approach. An existing seven storey reinforced concrete building situated in Indian seismic zone IV, which represents the typical properties of medium-rise non-ductile residential apartment buildings in India has been considered. Nonlinear seismic behavior of building with and without BMI is studied to evaluate seismic performance. Probabilistic seismic demand model (PSDM), fragility curves and damage probability matrix has been developed. Analytical fragility curves using incremental dynamic analysis have been developed. Sixteen natural ground motion records from PEER strong motion database are used to study the ground motion variability. Incremental dynamic analysis is performed and the maximum interstory drift is obtained as a response parameter for all simulations. The PSDM parameters are calculated using regression analysis for numerical models. The variation in the PSDM parameters is studied. Discrete probability matrices are developed for different damage stages. Finally, the effects of brick masonry infill on seismic performance are discussed.
\end{abstract}

Keywords Knowledge factor · Brick masonry infill $\cdot$ Incremental dynamic analysis $\cdot$ Fragility analysis $\cdot$ Damage probability matrix

$\begin{array}{ll}\text { Abbreviations } \\ \text { PEER } & \text { Pacific Earthquake Engineering Research } \\ \text { OMRF } & \text { Ordinary moment resisting frame } \\ \text { BMI } & \text { Brick masonry infill } \\ \text { FEMA } & \text { Federal Emergency Management Agency } \\ \text { PSDM } & \text { Probabilistic seismic demand model } \\ \text { IDA } & \text { Incremental dynamic analysis } \\ \text { IM } & \text { Intensity measures } \\ \text { MCE } & \text { Maximum considered earthquake } \\ \text { DCE } & \text { Design considered earthquake } \\ \text { ND } & \text { No damage } \\ \text { SD } & \text { Slight damage } \\ \text { MD } & \text { Moderate damage } \\ \text { CD } & \text { Complete damage } \\ \text { IO } & \text { Immediate occupancy } \\ \text { LS } & \text { Life safety }\end{array}$

V. S. Patil

vspatilcivil@gmail.com

1 Sanjay Ghodawat Group of Institutions affiliated to Shivaji University, Kolhapur 416004, India

2 Walchand College of Engineering affiliated to Shivaji University, Kolhapur 416004, India
CP Collapse prevention

HAZUS Hazards in US

\section{Introduction}

In India, BMI are considered as a nonstructural and neglects its contribution toward lateral load resistance. Smith and Carter (1970) proposed a method of analysis of infill frames based on an equivalent strut concept to predict the lateral stiffness of the composite frame. It is shown that for the typical case of a non-linear infill material the equivalent strut width is not a constant value but varies with the applied loading and the relative properties of the frame and infill. Due to the frame-infill interaction, the failure modes of the global structure may be changed. Four types of failure modes have been identified (Paulay and Priestley 1992) in case of in-filled frame buildings: (1) tension failure of the tension side column resulting from the applied overturning moments in in-filled frames with high aspect ratio, (2) sliding shear failure of the masonry along horizontal mortar bed joint causing shear hinges in the columns due to short column effect, (3) compression failure of the diagonal strut, and (4) diagonal tensile cracking of the panel. Asteris (2003) 
presented a new finite element technique for the analysis of brickwork in-filled plane frames under lateral loads and shown that the redistribution of shear force is critically influenced by the presence and continuity of infill panels. The presence of infill leads, in general, to decreased shear forces on the frame columns. However, in the case of an in-filled frame with a soft ground story, the shear forces acting on columns are considerably higher than those obtained from the analysis of the bare frame.

In the present study, an old building with open storey has been considered and the presence of BMI on seismic performance is studied by developing fragility curves and damage probability matrix. Fragility analysis is one of the steps in loss analysis in probabilistic evaluation methodology approach proposed by Pacific Earthquake Engineering Research (PEER). Various analytical approaches to performance-based earthquake engineering are in development. Rizzano and Tolone (2009), Dumova-Jovanoska (2000) developed a comprehensive methodology based on PEER approach for probabilistic performance evaluation. Porter (2003) summarizes the approach being pursued by the PEER Center. PEER methodology (Jalayer and Cornell 2003) works in four stages: hazard analysis, structural analysis, damage analysis, and loss analysis.

\section{Features of case study building}

The representative building selected is an actual structure situated in Indian seismic zone IV, built in 1980. It is a typical reinforced concrete seven-story building founded on medium soil. In plan, the structure's footprint is $19 \mathrm{~m} \times 10 \mathrm{~m}$ and in elevation it is $22.25 \mathrm{~m}$ tall as shown in Fig. 1. The original structure is an ordinary moment resisting reinforced concrete frame (OMRF). Cross section dimensions and reinforcement details of frame elements are shown in Tables 1 and 2, respectively. Non-destructive test has been carried out to obtain in situ compressive strength of concrete $\left(f_{\text {ck }}\right)$. It is difficult to obtain existing yield strength $\left(f_{\mathrm{y}}\right)$
Table 1 Reinforcement details in columns in example buildings

\begin{tabular}{llll}
\hline Title & Size in mm & Main steel $(\mathrm{Fe} 175)$ & Links $(\mathrm{Fe} 175)$ \\
\hline $\mathrm{C} 1$ & $230 \times 600$ & $12-20 \Phi$ & $6 \Phi @ 175 \mathrm{c} / \mathrm{c}$ \\
$\mathrm{C} 2$ & $230 \times 750$ & $12-20 \Phi$ & $6 \Phi @ 175 \mathrm{c} / \mathrm{c}$ \\
\hline
\end{tabular}

of embedded reinforcing steel and therefore, knowledge factor 0.7 (IS15988 2013) has been implemented. Accordingly, characteristic compressive strength of concrete $\left(f_{\mathrm{ck}}\right)$ as $14 \mathrm{MPa}$ and rebar yield strength $\left(f_{\mathrm{y}}\right)$ as $175 \mathrm{MPa}$ have been considered. The design live load and dead load on the floor area of building were taken as 3 and $6.5 \mathrm{kN} / \mathrm{m}^{2}$, respectively. Linear response spectrum analysis of original building using IS1893 (2016) design response spectrum, is performed to check the frame sections for seismic loading. It has been observe that columns at parking floor are weak in shear due to lower concrete strength and not satisfying beam-column capacity criteria (BCC).

To investigate the effect of BMI on seismic resistance, two models were considered as Model 1 and Model 2. Model 1 is a case study building with open ground floor and Model 2 is a case study building without open ground floor. Parking ground floor in Model 1 is closed in Model 2 by constructing brick walls in between columns as per the plan shown in Fig. 1a). In both the models contribution of BMI towards lateral strength and stiffness of the building is considered.

Elastic modal analysis is performed in SAP2000v15 on two models to study the dynamic behavior under different vibration modes, results are shown in Table 3. $U_{\mathrm{X}}$ and $U_{\mathrm{Y}}$ are showing translation motion and $R_{\mathrm{X}}, R_{\mathrm{Y}}$ and $R_{\mathrm{Z}}$ are showing rotational motion along the respective directions. Due to BMI in Model 2, the stiffness of the building has been increased, and therefore, fundamental period is reduced as compare with the fundamental of Model 1 (refer column 3 and 4 in Table 3). Relative mass participation of Model 2 in fundamental mode has been reduced as compare to Model 1, which shows contribution of higher modes has been increased. This is expected behavior of BMI building,

Fig. 1 Example building

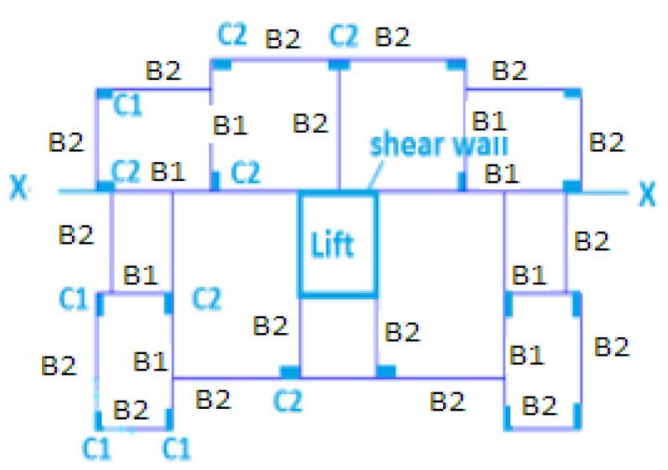

(a) Plan

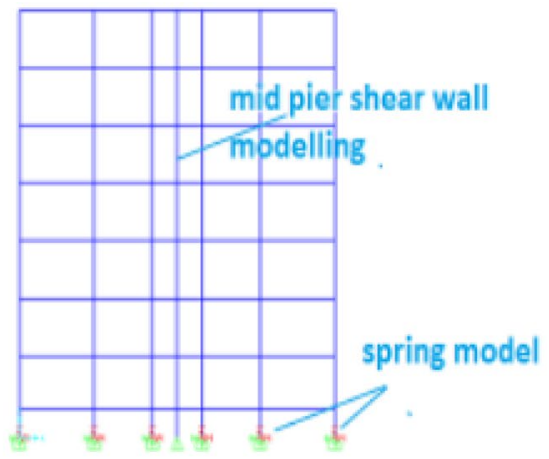

(b) Section $X-X$ 
in which bending mode is dominant over shear mode (refer column 5 and 6 in Table 3). The building is with asymmetric plan, and therefore, torsion mode is significant (see column 9 in Table 3).

Due to presence of BMI in Model 2, axial forces in the column in tension and compression side were increased and bending moment was reduced as shown in Fig. 2. Under lateral loading, BMI behaves as diagonal strut and hence truss action is dominant than flexure action (Smith and Carter 1970). This increase in axial forces in column may result in yielding of column prior to yielding of beam. Thus, in presence of BMI, ductility of the building gets reduced; $P$-delta effect will also be reduced due to reduction of lateral displacement.
Table 2 Reinforcement details in beams in example buildings

\begin{tabular}{|c|c|c|c|c|}
\hline \multirow[t]{2}{*}{ Title } & \multirow[t]{2}{*}{ Size in $\mathrm{mm}$} & \multicolumn{2}{|c|}{ Main steel (Fe175) } & \multirow{2}{*}{$\begin{array}{l}\text { Shear reinforcement (fe175) } \\
\text { Near end }\end{array}$} \\
\hline & & At top near end & At bottom at center & \\
\hline B1 & $230 \times 450$ & $6-16 \Phi$ & $2-16 \Phi+2-12 \Phi$ & 3-lgd 6Ф@150c/c \\
\hline B2 & $230 \times 375$ & $6-12 \Phi$ & $2-16 \Phi+2-12 \Phi$ & 6Ф@150c/c \\
\hline
\end{tabular}

\begin{tabular}{|c|c|c|c|c|c|c|c|c|}
\hline \multirow[t]{2}{*}{ Model } & \multirow[t]{2}{*}{ Mode no. } & \multicolumn{2}{|c|}{ Time period $(\mathrm{S})$} & \multicolumn{5}{|c|}{ Modal mass participation factor (unit less) } \\
\hline & & UX & UY & $\operatorname{SUM} U_{X}$ & $\operatorname{SUM} U_{Y}$ & $\operatorname{SUM} R_{X}$ & $\operatorname{SUM} R_{Y}$ & SUM $R_{Z}$ \\
\hline 1 & 2 & 3 & 4 & 5 & 6 & 7 & 8 & 9 \\
\hline \multirow[t]{3}{*}{ Model 1} & 1 & 0.59 & 0.551 & 0.8192 & $5.7 \times 10^{-7}$ & $5.4 \times 10^{-7}$ & 0.45 & 0.025 \\
\hline & 2 & 0.21 & 0.23 & 0.8192 & 0.98 & 0.77 & 0.45 & 0.52 \\
\hline & 3 & 0.12 & 0.11 & 0.9829 & 0.98 & 0.77 & 0.54 & 0.98 \\
\hline \multirow[t]{3}{*}{ Model 2} & 1 & 0.26 & 0.27 & 0.78 & $5.48 \times 10^{-7}$ & $5.3 \times 10^{-7}$ & 0.44 & 0.024 \\
\hline & 2 & 0.13 & 0.14 & 0.78 & 0.94 & 0.76 & 0.44 & 0.50 \\
\hline & 3 & 0.09 & 0.08 & 0.94 & 0.94 & 0.76 & 0.52 & 0.94 \\
\hline
\end{tabular}

Fig. 2 Axial force and bending moment distribution in column (-ve for compression)
Table 3 Dynamic properties of example buildings

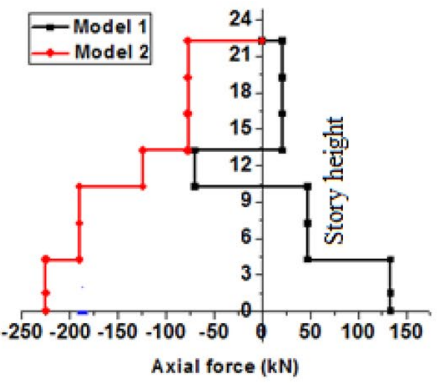

(a) Axial force in column in tension side

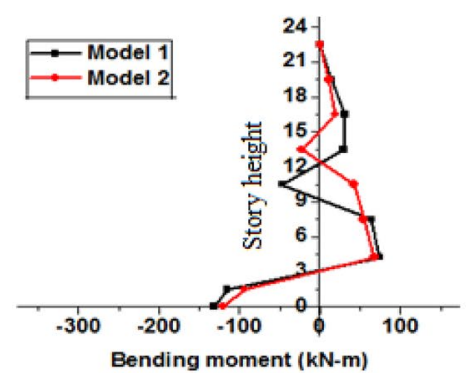

(c) B.M.in column in tension side

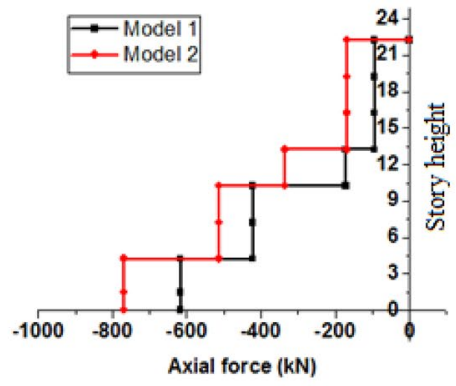

(b) Axial force in column in compression side

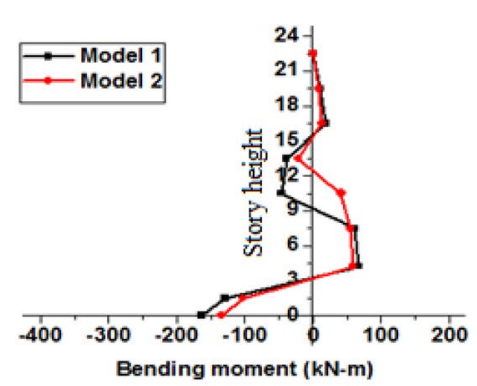

(d) B.M.in column in compression side 


\section{Modeling approach and assumptions}

Under seismic loading, the building deforms in nonlinear range. Nonlinear methods are essential to study the true behavior. Two kinds of nonlinearity are required to assign to different elements of the building. First is material nonlinearity and second is geometric nonlinearity.

\section{Material nonlinearity}

\section{Modeling of beam and column}

The associated material nonlinearity in the frame elements can be modeled by introducing plastic hinges. All the nonlinearity has been concentrated at the faces of the elements by introduction of plastic hinges. At the same location, two hinges are required to assign, one is flexural hinge and other is shear hinge. Flexural hinge addresses flexural failure and shear hinge addresses shear failure. Two stiff zones have been considered at the ends of the elements, to model the finite size of joints. Between two hinges at the ends, the element portion has been considered as elastic.

\section{Flexural hinge}

Figure 3a shows force deformation behavior for flexural hinge. For column, PMM hinge and for the beams M3 hinge interaction is assigned. As per FEMA356 (2000), flexural hinge is deformation controlled hinge. The definition of flexural hinge requires moment-rotation $(M-\theta)$ analysis. But in SAP2000v19, this hinge is assigned directly at the ends of the member by auto hinge option which saves the computational effort and the user does not require to perform $M-\theta$ analysis. Software does the calculations for given section at the end, percentage of tension reinforcement, grade of materials and axial load intensity. It uses the modeling parameters from FEMA356 (2000, Tables 6 and 7).

\section{Shear hinge}

Figure $3 \mathrm{~b}$ shows force deformation behavior for shear hinge. As per FEMA356 (2000), shear hinge is force controlled hinge. To assign the shear hinge in SAP2000v19, the shear resisting capacity of column and beam is required. The shear resisting capacity is evaluated as per IS456 (2000). The total shear strength of each reinforced concrete member is calculated as the sum of the shear capacity of the concrete $\left(V_{\mathrm{c}}\right)$ and the shear capacity of the reinforcement $\left(V_{\mathrm{s}}\right)$ (Eqs. 1, 2 and 3 ).

Shear capacity of the concrete in beams, $V_{\mathrm{c}}=f_{\mathrm{ck}} b d$

Shear capacity of the concrete in columns, $V_{\mathrm{c}}=\left(1+\frac{3 P_{\mathrm{u}}}{A_{\mathrm{g}} f_{\mathrm{ck}}}\right) f_{\mathrm{ck}} b d$

Shear capacity of vertical stirrup in beams, $V_{\mathrm{s}}=\frac{0.87 f_{\mathrm{y}} A_{\mathrm{sv}} d}{S_{\mathrm{v}}}$

where $P_{\mathrm{u}}$ - constant gravity loading on column $(\mathrm{DL}+0.25$ LL), $A_{\mathrm{g}}$ - gross cross section of column, $f_{\text {ck }}$-characteristic compressive strength of concrete, $f_{\mathrm{y}}$-yield strength of steel reinforcement, $b$-width of section, $d$-effective depth of section, $A_{\mathrm{sv}}$ - area of vertical stirrups in beam, and $S_{\mathrm{v}}$ spacing of vertical stirrups in beam.

\section{Modeling of beam-column joint}

During earthquake, the internal forces from beam to column and vice versa, are transferred through beam-column joint by strut action which, takes place in concrete core (ACI 352R-02 2002). Therefore, the joint fails under shear. Shear failure of joints are modeled by assigning shear hinge in the joint. It is assigned as a forced controlled hinge (see Fig. 3b). Shear resisting capacity of the joint is estimated by the equation from FEMA356 (2000). As per the equation, the shear
Fig. 3 Force deformation behavior of plastic hinge (FEMA-356 2000)

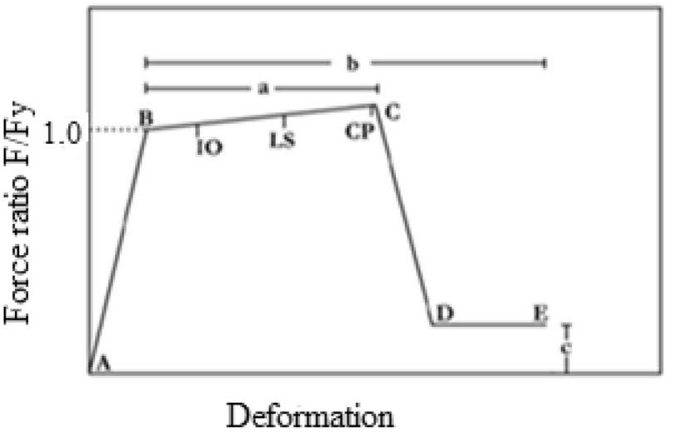

(a) Deformation controlled action

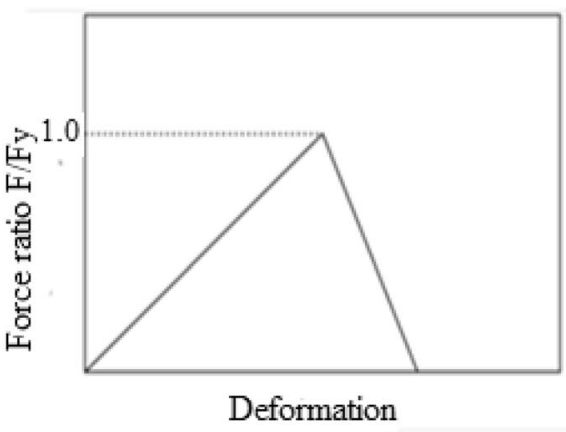

(b) Force controlled action 
capacity is depending on grade of concrete, dimensions of beam and column.

\section{Modeling of shear walls}

Shear walls are modeled as a mid-pier frame element and the nonlinearity has been defined by assigning plastic hinges defined according to FEMA356 (2000). Mid-Pier is modeled as a frame element with the shear wall cross sectional parameters (Rahman et al. 2012; Fahjan et al. 2010). Figure 4a represents the mid-pier frame model. The plastic $\mathrm{P}-\mathrm{M}-\mathrm{M}$ hinge is defined according FEMA356 (2000) with the given rebar distribution. The axial force level is considered from a combination of dead and live loads (DD + 0.25 LL) and the transverse reinforcing is assumed not to provide the confinement.

\section{Modeling of footings on soft soil}

For shallow bearing footings which are rigid with respect to the supporting soil, an uncoupled spring model as shown in Fig. 4b has been assigned. The Poisson's ratio and Young's modulus of 0.3 for sandy clay and $300 \mathrm{MPa}$ for gravels/sand well graded and dense, respectively, have been considered. The equivalent spring constants representing translation and rocking stiffness's are assigned as per ASCE/SEI 41-06 (2007) guidelines.

\section{Modeling of brick masonry infill}

Various researcher had been worked previously on modeling of brick infill under earthquake loading. Thiruvengadam (1985) proposed multiple strut model of infill panel by considering reciprocal stiffening effect. The model consists of a moment resisting frame with a number of pinjointed diagonal struts in both the directions. FEMA356 (2000) has proposed the diagonal strut model of infill by considering deformation controlled action with specified properties. This model can capture the frame infill interaction in global sense. Expected shear strength is considered as the control action and drift of the infill as corresponding deformation parameter. It has zero stiffness in extension and bending. It also has zero out of plane stiffness. This model has been used in the present study to investigate the effect of infill on behavior of frame buildings.

\section{Geometric nonlinearity}

This nonlinearity is with respect to shape change under seismic loading in which, the relation between strain-displacement is nonlinear. This is also called as $P$-delta effect. In SAP2000v15, this effect is included in the analysis by selecting $P$-delta option.

\section{Incremental dynamic analyses}

Researchers and standards have used an inelastic static pushover analysis in the past to estimate building capacity under various damage states. It provides insight into the structural response behavior at large displacement, but considers the first mode static response only, which is basically different from dynamic response. As a result, such analysis generally over-predicts the response and underestimates the capacity. Improvements can be made by considering higher modes via modal pushover analysis as shown by Chopra and Goel (2002). Vamvatsikos and Cornell (2005) extended the concept of Pushover analysis to dynamic response in the form of incremental dynamic analysis (IDA). The system capacity is evaluated by dynamic response analyses of the system under a suite of ground motion time histories, which are increased in intensity causing the structural response to increase from the linear elastic range into the nonlinear inelastic range and finally to the point where the structure finally becomes unstable, i.e., a large increase in interstory drift value (EDP) with a small increase in the spectral acceleration (IM). The displacement at this final point is defined as the system displacement capacity against collapse. The uncertainty in capacity against damage states can be described in terms of the mean and standard deviation of the interstory drift capacity under multiple recorded ground motions from IDA.
Fig. 4 Nonlinear modeling of shear wall and rigid footing. a Mid pier modeling for shear wall (Fahjan et al. 2010); b uncoupled spring model for rigid footings (ASCE/SEI 41-06 ASCE/SEI 41-06 2007)

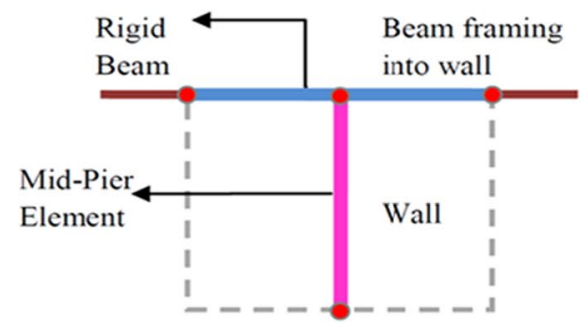

(a)
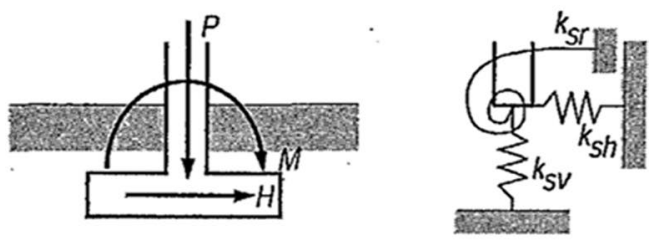

(b) 


\section{Selection of ground motion records}

Deciding on the number of ground motion records to be used in nonlinear time history analysis is a subject that researchers (Shome and Cornell 1999; Vamvatsikos and Cornell 2002) and seismic standards (FEMA P695 2009) are debating. The selection of ground motion records plays an important role to achieve reasonably accurate results with a limited number of analyses. In general, IDA capacity curves exhibit large record-to-record variability; hence, a suite of records is utilized to get reasonable estimation of seismic response. In present study, the ground-motion records are selected on the basis of parameters described in FEMA P695 (2009). The parameters considered for selection are earthquake magnitude $(\mathrm{Mw}>6)$, source-to-site distance $(<10 \mathrm{~km})$, number of records per station (only two horizontal component), PGA $(>0.2 \mathrm{~g})$, PGV $(>15 \mathrm{~cm} / \mathrm{s})$, moment magnitude ( $>6.5)$, etc. Sixteen records from eight seismic stations (pairs in two horizontal component directions) have been selected from the PEER strong motion database for IDA. The selected ground motion (GM) records are shown in Table 4.

\section{Scaling of ground motion records}

The actual ground motions which are recorded at different sites have different characteristics in terms of peak ground acceleration (PGA), frequency content and duration. The time domain scaling of ground-motion records alters their
PGA while the duration and frequency content remains unaltered. The ground-motions are either scaled up or down depending on the structure's capacity to the intensity level which causes the dynamic instability. Vamvatsikos and Cornell (2002) have suggested a methodology based on direct scaling with respect to $S_{\mathrm{a}}(T 1,5 \%)$. Shakib and Pirizadeh (2014) explains the scaling with respect to geometric mean of spectral acceleration for a period range of $0.5 T 1-1.5 T 1$, i.e., $S_{\mathrm{a}}, \mathrm{GM}(0.5 T 1-1.5 T 1,5 \%)$. Scaling procedure adopted for the present study is from FEMA P695 (2009), which states that scaling with respect to peak ground velocity (PGV) is a simple way to remove unwarranted variability between records due to inherent differences in event magnitude, source-to-site distance, source type and site condition. It recommends a two-step methodology for scaling of ground motions. The individual records are first normalized by their respective peak ground velocity, which is the geometric mean of the two horizontal components. In the second step, the median of the normalized record set is scaled upward or downward with respect to $S_{\mathrm{a}}(T 1,5 \%) . S_{\mathrm{a}}(T 1,5 \%)$ has been used as scaling parameter. The minor component has been scaled with the same factor as major component to maintain the ratio of the two components.

\section{Selection of IM and EDP}

Intensity measures (IM) is a ground motion measuring parameter. Different IM's are base shear, peak ground

Table 4 Ground motion database for IDA

\begin{tabular}{|c|c|c|c|c|c|c|c|c|}
\hline $\mathrm{GM}$ & Event & Station & ${ }^{\mathrm{a}} \varnothing^{0}$ & $\begin{array}{l}V_{\mathrm{s} 30}^{\mathrm{b}} \\
\mathrm{m} / \mathrm{s}\end{array}$ & $M_{\mathrm{w}}$ & $\underset{\mathrm{jb}}{R \mathrm{c}}(\mathrm{km})$ & PGA (g) & $\mathrm{PGV} \mathrm{cm/s}$ \\
\hline 1 & Imperial Valley-02,19/5/1940 & El Centro Array \#9 & 180 & 213.44 & 6.95 & 6.09 & 0.28 & 34.0 \\
\hline 2 & Imperial Valley-02, 19/5/1940 & El Centro Array \#9 & 270 & 213.44 & 6.95 & 6.09 & 0.20 & 32.0 \\
\hline 3 & San Fernando, 9/2,1971 & Pacoima Dam (upper left abut)" & 164 & 2016.1 & 6.61 & 0.0 & 1.20 & 125.0 \\
\hline 4 & San Fernando, 9/2,1971 & Pacoima Dam (upper left abut)" & 254 & 2016.1 & 6.61 & 0.0 & 1.20 & 55.0 \\
\hline 5 & Imperial Valley-06, 15/10/1979 & Bonds Corner & 140 & 223.03 & 6.53 & 0.44 & 0.58 & 21.0 \\
\hline 6 & Imperial Valley-06, 15/10/1979 & Bonds Corner & 230 & 223.03 & 6.53 & 0.44 & 0.80 & 40.0 \\
\hline 7 & Northridge-01,17,01,1994 & Arleta—Nordhoff Fire Station & 90 & 297.71 & 6.69 & 3.3 & 0.35 & 40.0 \\
\hline 8 & Northridge-01,17,01,1994 & Arleta—Nordhoff Fire Station & 360 & 297.71 & 6.69 & 3.3 & 0.32 & 22.0 \\
\hline 9 & Kobe_Japan, 16/01/1995 & KJMA & 0 & 312.0 & 6.9 & 0.94 & 0.70 & 86.0 \\
\hline 10 & Kobe_Japan, 16/01/1995 & KJMA & 90 & 312.0 & 6.9 & 0.94 & 0.60 & 85.0 \\
\hline 11 & Chi-Chi_Taiwan, 20/9/1999 & TCU136 & $\mathrm{N}$ & 462.1 & 7.6 & 8.27 & 0.18 & 50.0 \\
\hline 12 & Chi-Chi_Taiwan, 20/9/1999 & TCU136 & W & 462.1 & 7.6 & 8.27 & 0.2 & 45.0 \\
\hline 13 & Loma Prieta, 18/10/1989 & Los Gatos-Lexington Dam & 0 & 281.61 & 6.9 & 3.22 & 0.42 & 86.0 \\
\hline 14 & Loma Prieta, 18/10/1989 & Los Gatos-Lexington Dam & 90 & 281.61 & 6.9 & 3.22 & 0.4 & 98.0 \\
\hline 15 & Niigata_Japan, 23/10/2004 & NIG020 & EW & 331.6 & 6.6 & 7.45 & 0.5 & 30.0 \\
\hline 16 & Niigata_Japan, 23/10/2004 & NIG020 & NS & 331.6 & 6.6 & 7.45 & 0.43 & 25.0 \\
\hline
\end{tabular}

${ }^{\mathrm{a}}$ Component

${ }^{\mathrm{b}}$ Average shear wave velocity in upper $30 \mathrm{~m}$ of soil

${ }^{\mathrm{c}}$ Joyner-Boore horizontal distance to surface projection of the rupture 
acceleration (PGA, peak ground displacement (PGD), $S_{\text {a }}$ $(T 1,5 \%)$ etc. In the present study $S_{\mathrm{a}}(T 1,5 \%)$ is used as a IM simply because it reflects both ground and structure response.

The structure's response corresponding to a given intensity of ground motion, is represented by engineering demand parameters (EDP). Vamvatsikos and Cornell (2002) suggested that the selection of EDP depends on the fact whether structural or non-structural performance is to be evaluated. Maximum inter-storey drift ratio $\left(\theta_{\mathrm{Max}}\right)$, roof drift ratio $\left(\theta_{\mathrm{RDR}}\right)$, and roof displacement $\left(\Delta_{\text {roof }}\right)$ are some of the parameters that are well correlated with structural performance and global dynamic instability. In the present study maximum inter-story drift ratio, has been chosen as EDP since most of codes (HAZUS 2003; FEMA356 2000) have defined different damage states based on maximum interstory drift values and also it reflect well with ductility parameters.

\section{Damage states}

Under the seismic excitation the structural model undergoes various damage states (DS). ASCE/SEI 41-6 (2007), FEMAP-58-2 (2012), FEMA356 (2000) have defined three damage states as Immediate occupancy (IO), Life safety (LS) and Collapse prevention (CP). Four damage states have been used by HAZUS (2003) such as slight damage, moderate damage, major damage, and collapse state. HAZUS (2003) defines these limit states based on the field observations after earthquakes and it uses concrete cracks for RC buildings as measure of damage. As present study is to develop analytical fragility curves based on numerical simulation, no direct observation of crack development is available, and therefore, interstory drift limits for different damage states are considered from FEMA356 (2000) and IDA.

Three damage states have been considered as IO, LS and CP. Inter-story drift ratio of slight damage (IO) and moderate damage (LS) states are referred from FEMA356 (2000). Since it is very difficult to predict the collapse state (CP) of building under seismic excitation, therefore, the median ( $50 \%$ fractile) of all IDA curves are used to determine the corresponding maximum inter-story drift ratio at which the median curves started to become a flat line (Wen et al. 2004). For the present study, the inter-story drift capacity for three limit states is summarized in Table 5 .

\section{Discussion on median IDA curves}

Time history analysis results are presented in the form of dynamic capacity curves for two models subjected to sixteen ground motions (GM) listed in Table 4. Figure 5a, b represents median curves for 16 GM's along $x$ - and along $y$-direction, respectively. Median curves for Model 1 shows frame softening behavior immediately after elastic stage indicating low resistance with increased deformations and this might be due to lower material strength, soft storey effect and lower column to beam capacity ratio. Median curves for BMI Model 2 shows hardening behavior indicating increased resistance before failure (Vamvatsikos and Cornell 2002). Such an increased resistance is might be because of increased strength and stiffness due to presence
Table 5 Inter-story drifts capacity for different damage states

Fig. 5 Median IDA curves. (Two vertical lines are indicating damage states at CP performance limit)

\begin{tabular}{llll}
\hline Model & \multicolumn{4}{l}{ Maximum inter-story drift ratio $(\theta$ max.) $\%$} & \\
\cline { 2 - 4 } & $\begin{array}{l}\text { Immediate occupancy } \\
\text { (IO) from FEMA356 }\end{array}$ & Life safety (LS) from FEMA356 & Collapse prevention (CP) from IDA \\
\hline 1 & $1 \%$ along $X, Y$ direction & $2 \%$ along $X, Y$ direction & $2.5 \%$ along $X, 3 \%$ along $Y$ \\
2 & $1 \%$ along $X, Y$ direction & $2 \%$ along $X, Y$ direction & $3.5 \%$ along $X, 4 \%$ along $Y$ \\
\hline
\end{tabular}

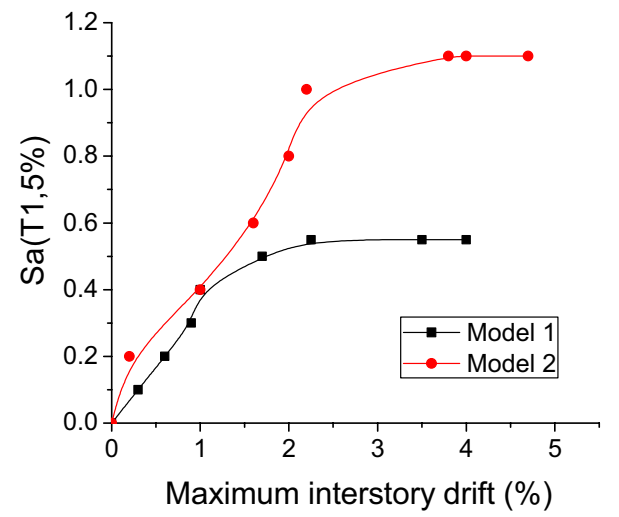

(a) X-direction

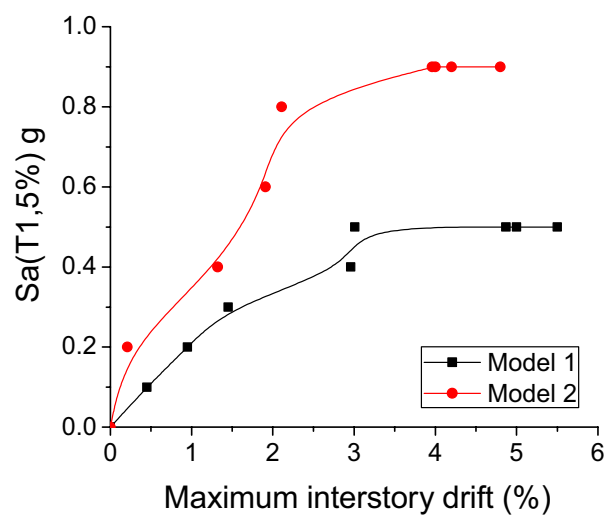

(b) Y-direction 
of infill. Median IDA curves shown in Fig. 5 give maximum interstory drift capacity values to define $\mathrm{CP}$ damage state. $\mathrm{CP}$ state are said to occur when the IDA curve becomes flat (Vamvatsikos and Cornell 2002). Table 5 shows the drift limits considered for $\mathrm{CP}$ damage states. It has been observed from Fig. 5 that, Model 1, has low resistance $(0.4 \mathrm{~g}$ along $x$-direction and $0.3 \mathrm{~g}$ along $y$-direction) to the earthquake excitation at collapse state (CP limit states) as compare with that of Model 2 ( $1 \mathrm{~g}$ along $x$-direction and $0.8 \mathrm{~g}$ along $y$-direction).

\section{Probabilistic seismic demand model and damage probability matrix}

A probability distribution for the demand conditioned on the intensity measure (IM) is known as a probabilistic seismic demand model (PSDM). The demand on the structure is quantified using some chosen metric(s) (e.g., inter storey drift and ductility). A regression analysis of the responses related to the limit state of interest as a function of the excitation intensity measure is then performed. Wen et al. (2004) have developed a methodology for determining probabilities of different damage states for reinforced concrete buildings through IDA. In this methodology, two-parameter power law has been fitted on the median EDP for a given IM. This power law represents a straight line in $\log -\log$ space and can be expressed as in Eq. 4,

$\ln \theta_{\max }=C_{1} \ln S_{\mathrm{a}}+C_{2}$

where $\theta_{\max }$ is the EDP for a given IM $S_{\mathrm{a}}$; and $C_{1}$ and $C_{2}$ are constants which are to determined from regression analysis. A proper distribution function (generally lognormal is a good fit) is then selected for EDP and based on which the fragility curve can be determined. The fragility function for limit states (LS) of damage, using IDA can be expressed as in Eq. 5 (Wen et al. 2004):

$P\left(\mathrm{LS} / S_{\mathrm{a}}\right)=1-\Phi\left[\frac{\lambda_{\mathrm{c}}-\lambda_{\mathrm{D} / \mathrm{Sa}}}{\sqrt{\beta_{\mathrm{D} / \mathrm{Sa}}^{2}+\beta_{\mathrm{c}}^{2}+\beta_{\mathrm{M}}^{2}}}\right]$

where $P\left(\mathrm{LS} / S_{\mathrm{a}}\right)=$ Probability of exceeding a limit state given the spectral acceleration at the fundamental period of the building; $\Phi=$ standard normal distribution; $\lambda_{\mathrm{c}}$ is the natural logarithm of median inter-story drift capacity at given limit states, $\lambda_{\mathrm{D} / \mathrm{Sa}}$ is the natural logarithm of median inter-story drift demand for a given spectral acceleration. $\beta_{\mathrm{D} / \mathrm{Sa}}$ and $\beta_{\mathrm{C}}$, are the variability parameters associated with demand and capacity, respectively, and are given as:

$\beta_{\mathrm{D} / \mathrm{S}_{\mathrm{a}}}=\sqrt{\ln \left(1+S^{2}\right)}$
$S^{2}=$ Standard error $=\sum \frac{\left(\ln Y_{\mathrm{i}}-\ln Y_{\mathrm{p}}\right)^{2}}{N-2}$

$\beta_{\mathrm{C}}=\sqrt{\ln (1+\mathrm{COV})^{2}}$,

where $Y_{\mathrm{i}}$ and $Y_{\mathrm{p}}$ are the observed and power law predicted median inter-story drift rotation values, respectively, for a given spectral acceleration $S_{\mathrm{a}}, N$ is the number of sample demand data points, and $\mathrm{COV}$ is the coefficient of variation of estimated inter-story drift capacity. $\beta_{\mathrm{M}}$ is the modeling uncertainty which is generally assumed equal to 0.40 as suggested in HAZUS (2003).

\section{Steps to construct fragility curve}

In the present study, sixteen ground motions listed in Table 4, have been taken for IDA. From IDA curve, values of spectral acceleration $\left(S_{\mathrm{a}}\right)$ corresponding to story drift $\left(\theta_{\max }\right)$ specified for three damage states has been obtained. Total 48 values were obtained. Then a graph between $\operatorname{Ln}\left(\theta_{\max }\right)$ on $x$-axis Vs. $\operatorname{Ln}\left(S_{\mathrm{a}}\right)$ on $y$-axis is plotted to obtained fragility parameters $C 1$ and $C 2$ in Eq. 4. Resulting graph with correlation equation and correlation factor is shown in Fig. 6.

Estimation of $\lambda$ c: Table 5 shows the limiting values of $\theta_{\max }$ for three limit states (LS). Then, the median capacity $\left(\lambda_{\mathrm{c}}\right)$ for each limit states is obtained by taking natural logarithm. As an example, the limiting value $\theta_{\max }$ for life safety (LS) damage state is $2 \%$. So the median drift capacity $\left(\lambda_{\mathrm{c}}\right)$ is, $\operatorname{Ln}(2)=0.693$.

Estimation of $\lambda_{(\mathrm{D} / \mathrm{Sa})}$ : This parameter is estimated using correlation equation. As an example, $\lambda_{(\mathrm{D} / \mathrm{Sa})}=(1.3951) \times \mathrm{Ln}$ $\left.\left(S_{\mathrm{a}}\right)_{1}+0.6942\right)$

Estimate of $\beta_{\mathrm{D} / \mathrm{Sa}}$ : Refer Eq. 6.

$Y_{\mathrm{i}}$ are the observed drift values, i.e., $\operatorname{Ln}\left(\theta_{\max }\right)$ and $Y_{\mathrm{p}}$ are the power law predicted drift values, i.e., $\lambda_{(\mathrm{D} / \mathrm{Sa})}$. Then

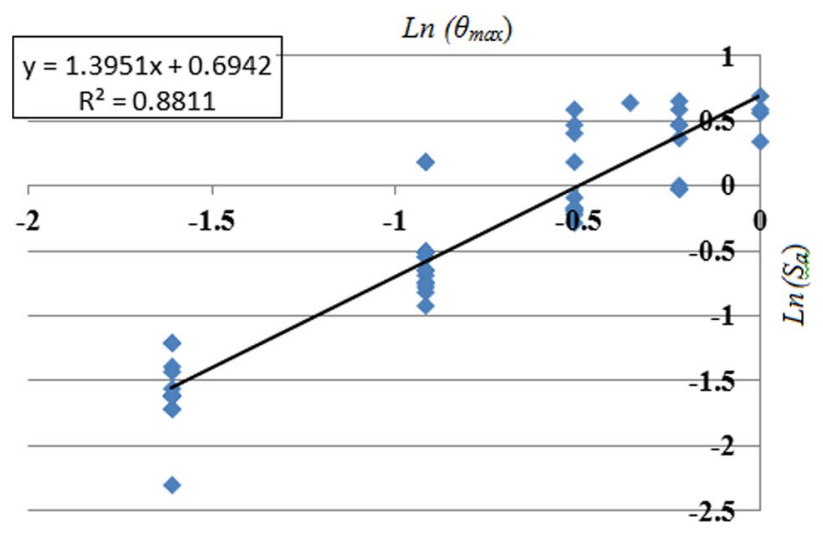

Fig. 6 Regression curve for model-1 (X-dir.) for LS damage states 
standard error $\left(S^{2}\right)$ using Eq. 7 is estimated. The value of $N$ for the present study is 16 .

Estimation of $\beta_{\mathrm{c}}$ : COV is estimated by the Eq. 9 and then $\beta_{\mathrm{c}}$ is estimated using Eq. 8.

$\mathrm{COV}=\frac{\sum\left(X_{\mathrm{i}}-X\right)\left(Y_{\mathrm{i}}-Y\right)}{N-1}$,

where $X_{\mathrm{i}}=$ the independent variable, $Y_{\mathrm{i}}=$ the dependent variable, $N=$ number of data points in the sample, $X=$ the mean of the independent variable $x, Y=$ the mean of the dependent variable $y$.

Fragility plot: All above estimated parameters are substituted in Eq. 5 to plot fragility curves.

\section{Damage probability matrix}

To underline the influence of the masonry infill walls, particular damage probability matrices have been obtained for maximum considered earthquake (MCE) and design basis earthquake (DBE). These are the two seismic hazard levels defined in IS1893 (2016). Three fragility curves corresponding to IO, LS and CP damage states have been developed for each model in two directions, and therefore, four damage stages are considered as No damage (ND), Slight damage (SD), Moderate damage (MD) and Collapse damage (CD) stage. Table 8 presents discrete damage probability matrices results. Discrete damage probabilities can be calculated as follows:
Probability of no damage, $\mathrm{P}[\mathrm{ND}]=1-\mathrm{P}\left[\mathrm{IO} \mid S_{\mathrm{a}}\right]$

Probability of slight damage (SD), $\mathrm{P}[\mathrm{SD}]=\mathrm{P}[\mathrm{IO} \mid \mathrm{Sa}]-$ $\mathrm{P}\left[\mathrm{LS} \mid S_{\mathrm{a}}\right]$

Probability of moderate damage (MD), P[MD] = $\mathrm{P}\left[\mathrm{LS} \mid S_{\mathrm{a}}\right]-\mathrm{P}\left[\mathrm{CP} \mid S_{\mathrm{a}}\right]$

Probability of complete damage (CD), $\mathrm{P}[\mathrm{CD}]=$ $\mathrm{P}\left[\mathrm{CP} \mid S_{\mathrm{a}}\right]-0$

\section{Discussion on fragility curves}

1. Table 6 presents the obtained fragility curve parameters. It has been observed that demand uncertainty $\left(\beta_{\mathrm{D} / \mathrm{Sa}}\right)$ for two models along two directions is nearly same and capacity uncertainty $\left(\beta_{\mathrm{c}}\right)$ for Model 2 is higher due to higher value of $\theta_{\max }$ than Model 1.

2. Figure 7 presents the fragility curves for collapse limit state (CP) for two models in both directions. Table 7 presents the obtained probability results. From Fig. 7, it has been observed that, along long direction ( $x$-direction) the two models shows similar performance for DBE and MCE level of seismic hazard but along short direction (y-direction) BMI Model 2 shows substantial improvement showing less probability to CP limit states indicating increase in strength and stiffness due to infill and hence showing improved performance. Thus, infill effect has been seen along short direction.

3. Figures 8 and 9 show fragility curves for two models along $x$-direction and along $y$-direction. For Model 1
Table 6 Estimated fragility parameters

\begin{tabular}{|c|c|c|c|c|c|c|c|c|c|c|c|c|}
\hline \multirow[t]{2}{*}{ Model } & \multirow[t]{2}{*}{ Damage states } & \multicolumn{2}{|l|}{$\beta_{c}$} & \multicolumn{2}{|l|}{$\beta_{\mathrm{DSa}}$} & \multirow{2}{*}{$\begin{array}{l}\beta_{M} \\
X \text { and } Y\end{array}$} & \multicolumn{2}{|l|}{$C 1$} & \multicolumn{2}{|l|}{$C 2$} & \multicolumn{2}{|l|}{$R^{2}$} \\
\hline & & $X$ & $Y$ & $X$ & $Y$ & & $X$ & $Y$ & $X$ & $Y$ & $X$ & $Y$ \\
\hline \multirow[t]{3}{*}{1} & $\mathrm{IO}$ & 0.52 & 0.47 & 0.29 & 0.34 & 0.4 & 1.8 & 1.77 & 1.47 & 1.33 & 0.85 & 0.86 \\
\hline & LS & 0.54 & 0.51 & 0.49 & 0.4 & 0.4 & 1.83 & 1.86 & 1.82 & 1.88 & 0.84 & 0.85 \\
\hline & $\mathrm{CP}$ & 0.5 & 0.52 & 0.31 & 0.32 & 0.4 & 1.92 & 1.88 & 2.0 & 1.92 & 0.86 & 0.86 \\
\hline \multirow[t]{3}{*}{2} & $\mathrm{IO}$ & 0.44 & 0.44 & 0.33 & 0.33 & 0.4 & 1.93 & 1.98 & 0.4 & 0.43 & 0.85 & 0.85 \\
\hline & LS & 0.44 & 0.43 & 0.39 & 0.39 & 0.4 & 1.90 & 1.90 & 0.62 & 0.62 & 0.9 & 0.91 \\
\hline & $\mathrm{CP}$ & 0.53 & 0.54 & 0.37 & 0.36 & 0.4 & 1.98 & 1.95 & 0.73 & 0.68 & 0.84 & 0.83 \\
\hline
\end{tabular}

$\left(R^{2}\right.$-represents goodness of fit on median power law)
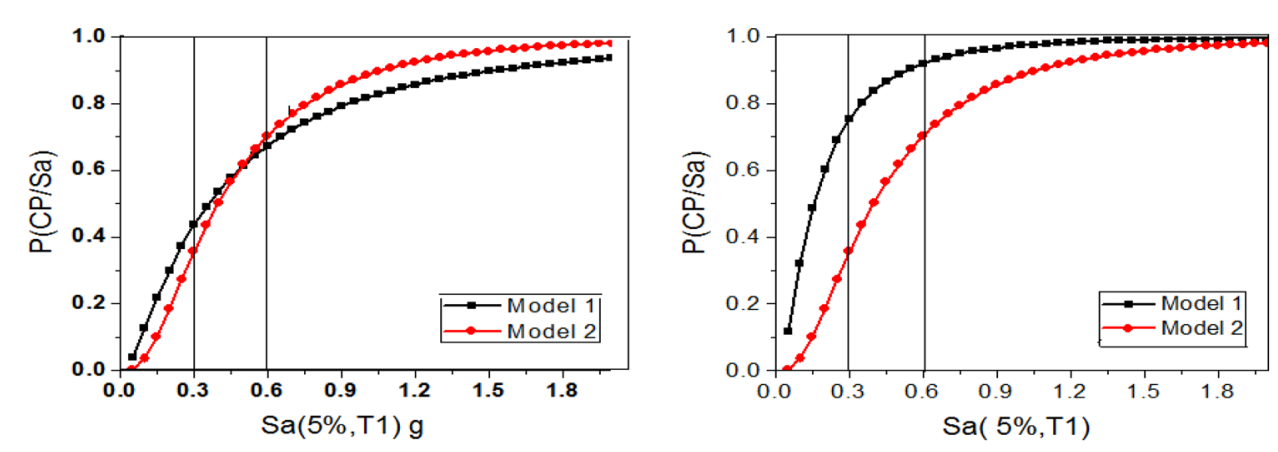

Fig. 7 Fragility curves for $\mathrm{CP}$ limit states for both model in $x$ and $y$-direction 
Table 7 Probabilities corresponding to DBE and MCE hazards along both directions

\begin{tabular}{|c|c|c|c|c|c|c|c|c|c|c|c|c|}
\hline \multirow[t]{3}{*}{ Model } & \multicolumn{6}{|l|}{ DCE } & \multicolumn{6}{|l|}{ MCE } \\
\hline & \multicolumn{3}{|c|}{$X$-direction } & \multicolumn{3}{|c|}{$Y$-direction } & \multicolumn{3}{|c|}{$X$-direction } & \multicolumn{3}{|c|}{$Y$-direction } \\
\hline & IO (\%) & LS (\%) & $\mathrm{CP}(\%)$ & $\mathrm{IO}(\%)$ & LS (\%) & $\mathrm{CP}(\%)$ & $\mathrm{IO}(\%)$ & LS (\%) & $\mathrm{CP}(\%)$ & $\mathrm{IO}(\%)$ & LS (\%) & $\mathrm{CP}(\%)$ \\
\hline 1 & 80 & 8 & 5 & 40 & 40 & 25 & 99 & 55 & 30 & 80 & 75 & 65 \\
\hline 2 & 35 & 10 & 8 & 78 & 35 & 7 & 70 & 40 & 35 & 85 & 68 & 25 \\
\hline
\end{tabular}

Fig. 8 Fragility curves for three limit states for model- 1 in $x$-and $y$-direction
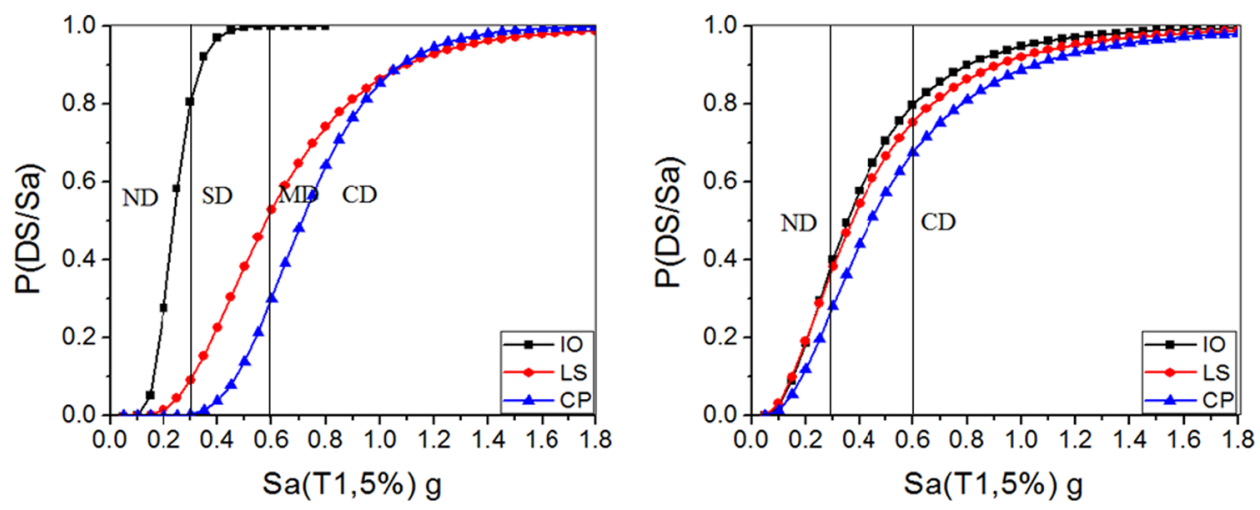

Fig. 9 Fragility curves for three limit states for model-2 in $x$ and $y$-direction. (The two vertical lines represent the seismic demand corresponding to DBE and MCE hazards)

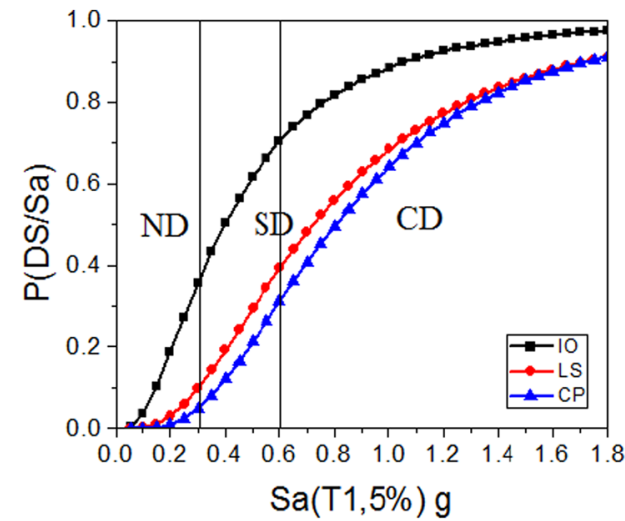

Table 8 Damage probability matrix for MCE and DBE level

\begin{tabular}{|c|c|c|c|c|}
\hline \multirow[t]{3}{*}{ Damage state } & \multicolumn{2}{|c|}{ Model-1 } & \multicolumn{2}{|c|}{ Model-2 } \\
\hline & \multicolumn{4}{|c|}{ For MCE seismic demand level } \\
\hline & $X$-dir. & $Y$-dir. & $X$-dir. & $Y$-dir. \\
\hline No damage (ND) (\%) & 2 & 22 & 35 & 15 \\
\hline Slight damage (SD) (\%) & 48 & 3 & 27 & 20 \\
\hline Moderate damage (MD) (\%) & 20 & 10 & 8 & 35 \\
\hline \multirow[t]{2}{*}{ Complete damage (CD) (\%) } & 30 & 65 & 30 & 30 \\
\hline & \multicolumn{4}{|c|}{ For DBE seismic demand level } \\
\hline No damage (ND) (\%) & 20 & 60 & 62 & 25 \\
\hline Slight damage (SD) (\%) & 70 & 2 & 28 & 37 \\
\hline Moderate damage (MD) (\%) & 5 & 13 & 2 & 30 \\
\hline Complete damage (CD) (\%) & 5 & 25 & 8 & 8 \\
\hline
\end{tabular}

which is without infill, the curves (Fig. 8) are closer to each other as compare with the fragility curves for Model 2 (Fig. 9) indicating that the building crossing the damage stages one by one but immediately due to lower resistance. Fragility curves for Model 2 (Fig. 9) along short direction are well spaced as compare with the fragility curves along long direction indicating the effectiveness of infill in all stages of damage.

4. To underline the influence of the masonry infill walls, discrete damage probability matrix has been obtained for MCE and DBE level of seismic demand. Table 8 and Figs. 10, 11 present the obtained results. Results along short direction shows that probability values are consistent from ND stage to MD stage which means that infill is contributing consistently to resist seismic 


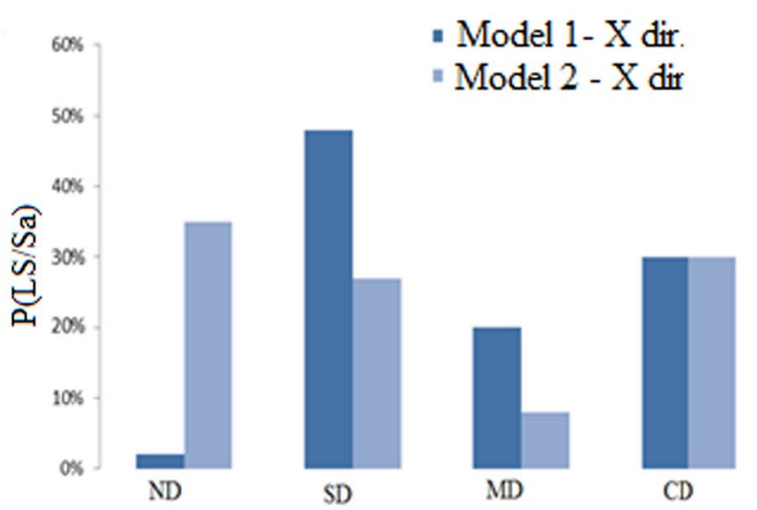

Fig. 10 Probability matrix for two models for MCE seismic hazard

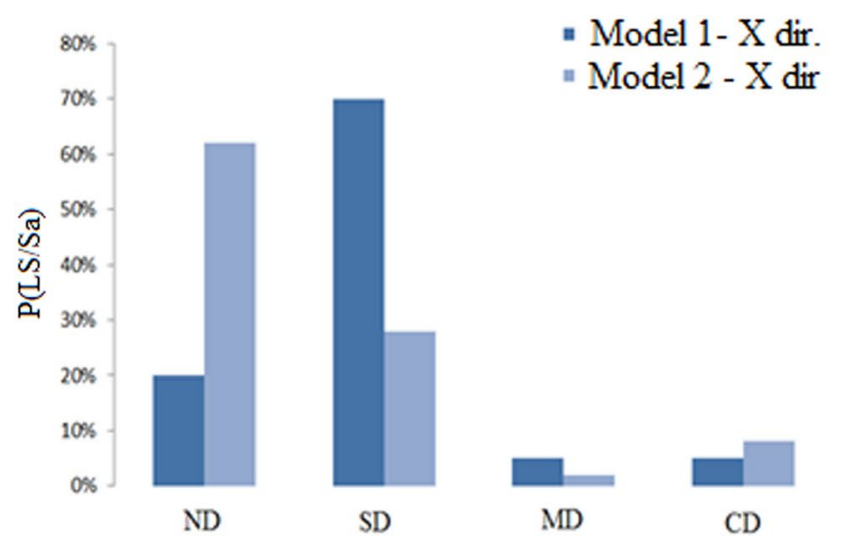

Fig. 11 Probability matrix for two models for DBE seismic hazard

demand between these stages and in the last stage (CD) it is showing low probability compare to model1 indicating higher resistance to collapse. Thus, we may say that along short direction infill is effective in all stages of damage states. Along longer direction the trend is different and it is observed that infill is effective in the initial stages but in the later stages the performance of Model 1 and Model 2 are almost same.

\section{Conclusions}

This paper is study of effect of BMI on seismic performance of existing old building by probabilistic approach. Analytical fragility curves demonstrate the presence of BMI for different intensities of earthquake. In presence of BMI, the improvement of performance is shown along short direction as compare with long direction. Also for old buildings, the building offers resistance in between different damage states due to presence of BMI but for the building without BMI, the various performance damages are sudden one
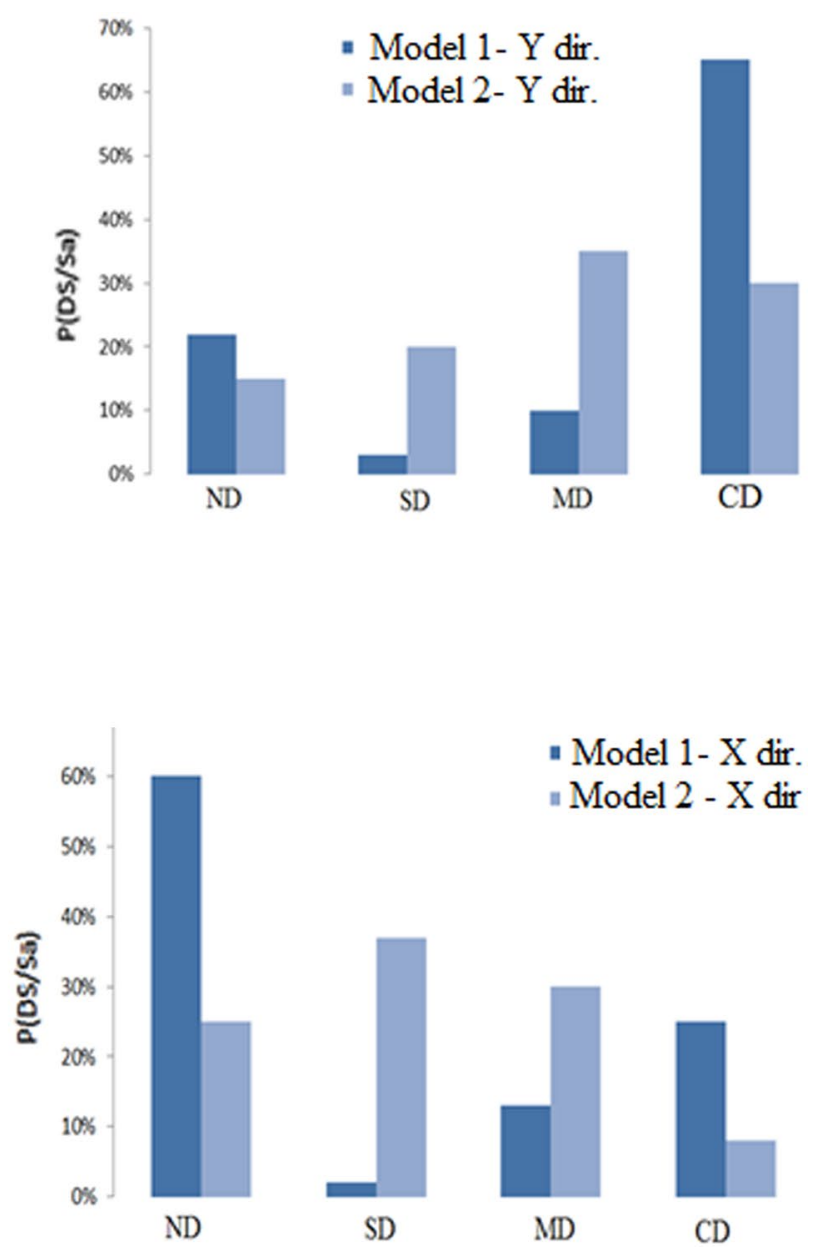

after other. At the end, the study recommends probabilistic performance-based study for the seismic performance evaluation of existing buildings than traditional strength-based design method.

Open Access This article is distributed under the terms of the Creative Commons Attribution 4.0 International License (http://creativeco mmons.org/licenses/by/4.0/), which permits unrestricted use, distribution, and reproduction in any medium, provided you give appropriate credit to the original author(s) and the source, provide a link to the Creative Commons license, and indicate if changes were made.

\section{References}

ACI 352R-02 (2002) Recommendations for design of beam-column connections in monolithic reinforced concrete structures. American Concrete Institute, Detroit

ASCE/SEI 41-06 (2007) Seismic rehabilitation of existing buildings. ASCE standard, American Society of Civil Engineers, Reston Asteris PG (2003) Lateral stiffness of brick masonry infilled plane frames. J Struct Eng ASCE 129(8):1071-1079 
Chopra AK, Goel RK (2002) A modal pushover analysis procedure for estimating seismic demands for buildings. Earthq Eng Struct Dyn 31(3):561-582

Dumova-Jovanoska E (2000) Fragility curves for reinforced concrete structures in Skopje (Macedonia) region. Soil Dyn Earthq Eng 19(2000):455-466

Fahjan YM, Kubin J, Tan MT (2010) Non-linear analysis methods for reinforced concrete buildings with shear walls. In: 14 ECEE, Ohrid, Macedonia

FEMA-356 (2000) Pre-standard and commentary for the seismic rehabilitation of buildings. Federal Emergency Management Agency, Washington, DC

FEMA P695 (2009) Quantification of building seismic performance factors. Federal Emergency Management Agency, Washington, DC

FEMA P-58-2 (2012) Seismic performance assessment of buildings. vol 2-implementation guide. Federal Emergency Management Agency, Washington, DC

HAZUS®MHMR4, Technical manual (2003) Multi-hazard loss estimation methodology earthquake model. Federal Emergency Management Agency, Washington, DC

IS456 (2000) Indian standard Plain and reinforced concrete, code of practice. Bureau of Indian Standards, New Delhi

IS15988 (2013) Indian standard. Seismic evaluation and strengthening of existing reinforced concrete buildings-guidelines. Bureau of Indian Standards, New Delhi

IS1893 Part 1 (2016) Indian standard. criteria for earthquake resistant design of structures, part 1: general provisions and buildings (Sixth revision). Bureau of Indian Standards, New Delhi

Jalayer F, Cornell CA (2003) A technical framework for probabilitybased demand and capacity factor design (DCFD) seismic formats. Pacific Earthquake Engineering Research Center PEER Report 2003/8, PEER Berkeley

Paulay T, Priestley M (1992) Seismic design of reinforced concrete and masonry buildings. Wiley, New York
Porter KA (2003) An overview of PEER's performance-based earthquake engineering methodology. In: Ninth international conference on applications of statistics and probability in civil engineering (ICASP9) July 6-9, 2003, San Francisco

Rahman MK, Ajmal M, Baluch MH (2012) Nonlinear Static pushover analysis of an eight story RC frame-shear wall building in Saudi Arabia. 15 WCEE Lisboa

Rizzano G, Tolone I (2009) Seismic assessment of existing RC frames: probabilistic approach. J Struct Eng ASCE 135(7):836-852

Shakib H, Pirizadeh M (2014) Probabilistic seismic performance assessment of setback buildings under bidirectional excitation. $\mathbf{J}$ Struct Eng 140(2):140-145

Shome N, Cornell CA (1999) Probabilistic seismic demand analysis of nonlinear structures. Rep. No. RMS-35, Department of Civil and Environmental Engineering, Stanford University, Stanford

Smith B, Carter C (1970) A method of analysis for infilled frames. Southampton College of Technology, University of SouthamptonICE Publishing, London

Thiruvengadm V (1985) On the natural frequencies of infilled frames. J Earthq Eng Struct Dyn 13:401-419

Vamvatsikos D, Cornell CA (2002) Incremental dynamic analysis. Earthq Eng Struct Dyn 31(3):491-514

Vamvatsikos D, Cornell C (2005) Direct estimation of seismic demand and capacity of multidegree-of-freedom systems through incremental dynamic analysis of single degree of freedom. J Struct Eng 131(4):589-599

Wen YK, Ellingwood BR, Bracci J (2004) Vulnerability function framework for consequence-based engineering, vol DS-4, MAE Center Project DS-4 Report

Publisher's Note Springer Nature remains neutral with regard to jurisdictional claims in published maps and institutional affiliations. 